Fascist Spectacle 
Studies on the History of Society and Culture Victoria E. Bonnell and Lynn Hunt, Editors

1. Politics, Culture, and Class in the French Revolution, by Lynn Hunt

2. The People of Paris: An Essay in Popular Culture in the Eighteenth Century, by Daniel Roche

3. Pont-St-Pierre, 1398-1789: Lordship, Community, and Capitalism in Early Modern France, by Jonathan Dewald

4. The Wedding of the Dead: Ritual, Poetics, and Popular Culture in Transylvania, by Gail Kligman

5. Students, Professors, and the State in Tsarist Russia, by Samuel D. Kassow

6. The New Cultural History, edited by Lynn Hunt

7. Art Nouveau in Fin-de-Siècle France: Politics, Psychology, and Style, by Debora L. Silverman

8. Histories of a Plague Year: The Social and the Imaginary in Baroque Florence, by Giulia Calvi

9. Culture of the Future: The Proletkult Movement in Revolutionary Russia, by Lynn Mally

10. Bread and Authority in Russia, 1914-1921, by Lars T. Lih

11. Territories of Grace: Cultural Change in the Seventeenth-Century Diocese of Grenoble, by Keith P. Luria

12. Publishing and Cultural Politics in Revolutionary Paris, $1789-1810$, by Carla Hesse

13. Limited Livelihoods: Gender and Class in Nineteenth-Century England, by Sonya O. Rose

14. Moral Communities: The Culture of Class Relations in the Russian Printing Industry, 1867-1907, by Mark Steinberg

15. Bolshevik Festivals, 1917-1920, by James von Geldern

16. Venice's Hidden Enemies: Italian Heretics in a Renaissance City, by John Martin

17. Wondrous in His Saints: Counter-Reformation Propaganda in Bavaria, by Philip M. Soergel

18. Private Lives and Public Affairs: The Causes Célèbres of Prerevolutionary France, by Sarah Maza

19. Hooliganism: Crime, Culture, and Power in St. Petersburg, 1900-1914, by Joan Neuberger

20. Possessing Nature: Museums, Collecting, and Scientific Culture in Early Modern Italy, by Paula Findlen

21. Listening in Paris: $A$ Cultural History, by James $\mathrm{H}$. Johnson

22. The Fabrication of Labor: Germany and Britain, 1640-1914, by Richard Biernacki

23. The Struggle for the Breeches: Gender and the Making of the British Working Class, by Anna Clark

24. Taste and Power: Furnishing Modern France, by Leora Auslander

25. Cholera in Post-Revolutionary Paris: A Cultural History, by Catherine J. Kudlick

26. The Women of Paris and Their French Revolution, by Dominique Godineau

27. Iconography of Power: Soviet Political Posters under Lenin and Stalin, by Victoria E. Bonnell

28. Fascist Spectacle: The Aesthetics of Power in Mussolini's Italy, by Simonetta Falasca-Zamponi

29. Passions of the Tongue: Language Devotion in Tamil India, 1891-1970, by Sumathi Ramaswamy 


\section{Fascist Spectacle}

The Aesthetics of Power in Mussolini's Italy

SIMONETTA FALASCA-ZAMPONI

University of California Press

BERKELEY LOS ANGELES LONDON 
University of California Press

Berkeley and Los Angeles, California

University of California Press, Ltd.

London, England

(i) 1997 by

The Regents of the University of California

Library of Congress Cataloging-in-Publication Data

Falasca-Zamponi, Simonetta, 1957-

Fascist spectacle : the aesthetics of power in Mussolini's Italy /

Simonetta Falasca-Zamponi.

p. $\mathrm{cm}$.-(Studies on the history of society and culture ; 28)

Includes bibliographic references and index.

ISBN 0-520-20623-1 (alk. paper)

1. Fascism-Italy. 2. Italy - Politics and government-

1922-1945. 3. Fascism and culture-Italy. 4. Aesthetics, Italian2oth century. I. Title. II. Series.

$\mathrm{DG}_{571 . F 2} 1997$

$320.5^{\prime} 33^{\prime} 0945$-dc2o

Printed in the United States of America

$\begin{array}{lllllllll}9 & 8 & 7 & 6 & 5 & 4 & 3 & 2 & 1\end{array}$

The paper used in this publication meets the minimum requirements of American National Standards for Information Sciences-Permanence of Paper for Printed Library Materials, ANSI Z39.48-1984. 
A Ugo e Marusca 
